\title{
INHIBITION OF LIPIDS OXIDATION IN THE MINCED MUSCLE TISSUE OF HERRING THROUGH USAGE OF SELECTED FRUITS IN THE CONDITIONS OF FREEZING STORAGE
} HAMOWANIE UTLENIANIA LIPIDÓW ZMIELONEJ TKANKI MIEŚNIO-
WEJ ŚLEDZI POPRZEZ ZASTOSOWANIE WYBRANYCH OWOCÓW
W WARUNKACH ZAMRAŻALNICZEGO PRZECHOWYWANIA

Chair of Fish Preservation, Agricultural University of Szczecin, Poland

In the present study the following fruits were applied as additives to the minced muscle tissue of the Baltic herring stored at the temperature of $-25^{\circ} \mathrm{C}$ : wild rose $(0.5 \%)$, sorb $(0.5 \%)$, hawthorn $(0.5 \%)$ and the mixture of sorb $(0.25 \%)$ with hawthorn $(0.25 \%)$. The assays were aimed at the content of hydroperoxides malonaldehyde, conjugated dienes and trienes and free fatty acids, and also their impact on the proteins solubility in $5 \% \mathrm{NaCl}$ solution.

\section{INTRODUCTION}

Antioxidants play important role in stabilizing lipids of food row materials during their storage and processing. Due to dietary, as well as therapeutic reasons, the importance of natural antioxidants occurring in plants, increases. It has been revealed in the course of studies on the activity of plant row materials in inhibiting oxidation of the fish lipids, that seeds of the wild rose, dwarf quince, their mixture, as well as pepper, applied to the minced muscle tissue of herring, indeed slowed down the process of lipids oxidation at the time of freezing storage (Stodolnik 1994, 1995). It is evident from the other publications (Löliger 1989; Larson 1988; Bartnikowska 1995) that the major antioxidative compounds, present in the fruits, as well as in the other parts of plants are: tocopherols, ascorbic acid, $\beta$-carotene, and flavonoids. The latter constitute the principal group of plant antioxidants of the phenol type, being acceptors of the free radicals (Pratt and Watts 1964) and of the action similar to that of BHA and BHT (St. Angelo et al. 1990). The other important function of the flavonoids is the inhibition of lipoxygenase activity and chelate ring formation with metal ions, iron in particular, which contribute to inhibition of lipids oxidation (Bartnikowska 1995). 
Fruits of wild bushes and trees contain much more biologically active compounds than their seeds. It has been proven (Wilska-Jeszka et al. 1988; Ożarowski and Jaroniewski 1989) that flesh of the wild rose contains multiple âmounts of ascorbic acid, flavonoids and carotenoids in particular, compared to the amounts in its seeds. The latter, as proved in the earlier studies (Stodolnik 1994, 1995) have extensive abilities of inhibiting oxidation of fish lipids. Having the above in mind, the studies have been initiated on defining the activity of the wild rose, hawthorn and the sorb in slowing down oxidation of lipids of the minced muscle tissue of herring during freezing storage. The experiments were related to the row material lacking such additives, and containing butylated hydroxyanisole (BHA).

\section{MATERIAL AND METHODS}

Baltic herring, of "D" size caught on the beginning of December 1994 constituted the material for the present study. The fish represented the third and fourth stage of gonad maturity in the Maier's scale and were at the ultimate, fading phase of rigor mortis. The herring were processed as skinned filets, minced in a grinding machine with 3-mm strainer. From the obtained minced muscle tissue, after its mixing, the experimental samples were prepared, containing the addition of previously dried, at the temperature of $40^{\circ} \mathrm{C}$, minced fruits of: wild rose (Rosa canina L.) in the concentration of $0.5 \%$, sorb (Sorbus aucuparia L.) in concentration of $0.5 \%$, hawthorn (Crataegus oxyacantha L.) in concentration of $0.5 \%$, and the mixture of sorb $(0.25 \%)$ and hawthom fruits $(0.25 \%)$. The other experimental variation was the minced muscle tissue with addition of $0.01 \%$ of BHA. Minced muscle tissue without any additives constituted the control sample. The minced muscle tissue varieties, after careful mixing, was divided into 60-g samples, which were formed as $1 \mathrm{~cm}$-thick bars, then wrapped in polyethylene foil and frozen at the temperature of $-25^{\circ} \mathrm{C}$. The storage, also at $25^{\circ} \mathrm{C}$, lasted 4 months. All experimental variants of the samples were defrosted prior to the analysis at the temperature of $4^{\circ} \mathrm{C}$.

Extraction of the lipids from the muscle tissue of herring was conducted using chloroform-methanol mixture (Linko 1967). The acquired extracts served for the following assays:

1. Content of the lipids - weight method, after distilling out the solvent under lowered pressure and drying up the reminder at $80^{\circ} \mathrm{C}$ within 1 hour.

2. Free fatty acids - thin-layer chromatography and densitometry method (Stodolnik 1994).

3. Content of hydroperoxides in the chloroform layer of the extracts, after their oxidation to malonaldehyde and the reaction with TBA (Schmedes and Holmer 1989).

4. Content of malonaldehyde (TBARS) in the metanol-water layer of the extracts using TBA (Schmedes and Holmer 1989).

5. Conjugated dienes and trienes of fatty acids - spectrophotometric method, using the reading of the absorbance of the chloroform layer of the extracts at wave length of 247 and $278 \mathrm{~nm}$ respectively and calculation of the absorption coefficient (Paquot 1979). 
Solubility of the proteins in $0.5 \%$ solution of $\mathrm{NaCl}\left(\mathrm{pH} \mathrm{7.2)}\right.$ ) at the temperature of $0^{\circ} \mathrm{C}$ was determined according to the procedure described in the earlier work (Stodolnik 1994). The results of the chemical assays are the arithmetic mean values from three paralell repetitions.

Antioxidative activity (AA) of the additives used was calculated based on the following formula (Al-Saikhan et al. 1995):

$$
\mathrm{AA}=\frac{\begin{array}{c}
\text { Content of the oxidation } \\
\text { products in the control } \\
\text { sample }
\end{array}}{\text { Content of the oxidation products in the control sample }} \times 100[\%]
$$

The statistical analysis covered the calculation of the correlation coefficient and its significance (Czermiński et al. 1979).

\section{RESULTS AND DISCUSSION}

The herring muscle tissue sampled for the assays contained $6.62 \%$ of lipids. Supplementing the minced muscle tissue of the fish with the fruits of hawthorn, sorb, and BHA and freezing preservation caused the reduction of the lipids quantities compared to the tissue without such additives. On the other hand, the wild rose fruits caused increase in the quantities extracted (Fig. 1).
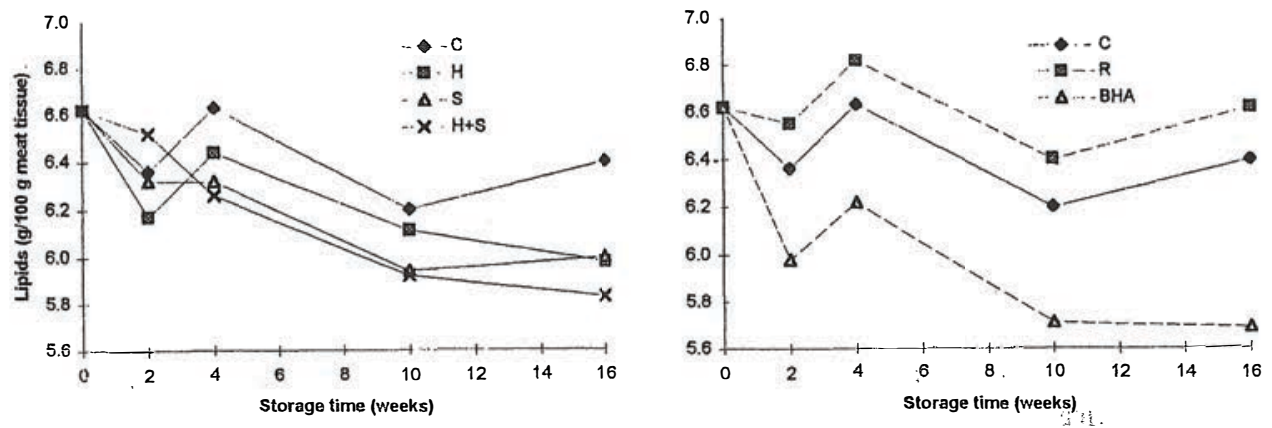

Fig. 1. Impact of the additives used for extraction of lipids from the muscle tissue of herring during frozen storage. $\mathrm{C}$ - control; with additives: $\mathrm{R}$ - rose, $\mathrm{S}$ - sorb, $\mathrm{H}$ - hawthorn, $\mathrm{BHA}$ - butylated hydroxyanisole

Gradual decrease in the lipids' extractivity from the muscle tissue of all analyzed variations of fish minced muscle tissue occurred throughout the whole period of storage of the 
Table 1 studied samples at the freezing conditions.

Correlation between the amount of the lipids extracted from the muscle tissue of herring and the time of frozen storage

\begin{tabular}{|l|c|c|}
\hline \multicolumn{1}{|c|}{ Kind of sample } & $\begin{array}{c}\text { Correlation } \\
\text { coefficient }\end{array}$ & $\begin{array}{c}\text { Significance } \\
\text { level }\end{array}$ \\
\hline Control & -0.435 & 0.30 \\
Additive used: & & \\
Hawthorn & -0.757 & 0.02 \\
Sorb & -0.826 & 0.01 \\
Hawthorn + sorb & -0.914 & 0.001 \\
Rose & -0.107 & 0.80 \\
BHA & -0.777 & 0.01 \\
\hline
\end{tabular}

Dependence of such changes on the storage time, calculated based on the correlation coefficients, was significant for the majority of the samples (Tab. 1). Only for the muscle tissue containing the additive of the wild rose, such relationship was small, and the value of the correlation coefficient was meaningful only for $p \geq 0.8$ (Tab. 1).

The revealed tendencies of changes in the lipids' extractivity from the muscle tissue stored at the temperature of $-25^{\circ} \mathrm{C}$ do not have clear confirmation in the earlier studies (Stodolnik 1994, 1995), performed on the row material of very similar content of lipids in the muscle tissue. These contents were 6.35 and $6.34 \%$ respectively and the studied materials were stored at the similar conditions, but both came from different fishing seasons (October and March respectively). The probable cause of the revealed changes in the extractivity of the lipids were differences in the muscle structure and the percentage content of the connective tissue in the fish caught at different year seasons (Love 1988).
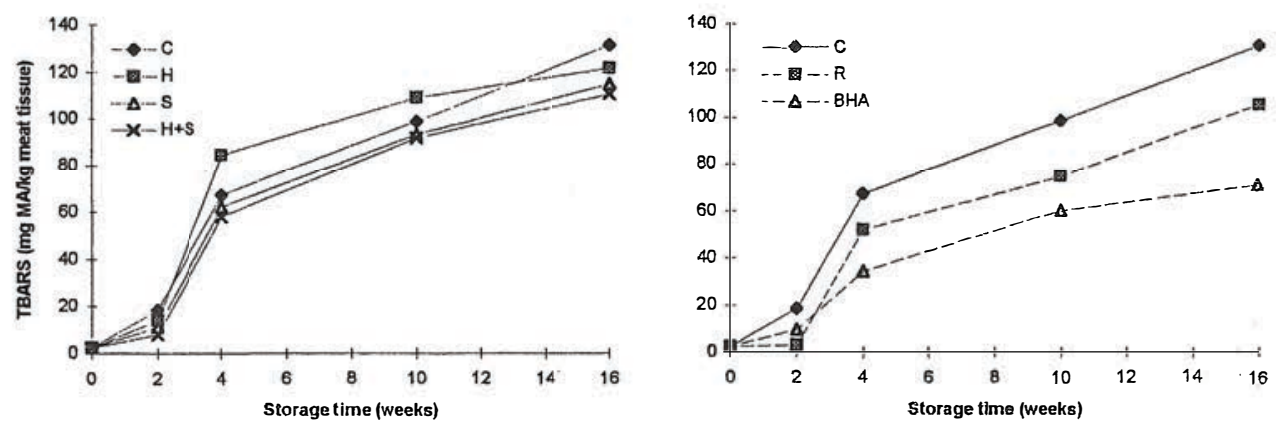

Fig. 2. Impact of the additives used for oxidation of the lipids of the muscle tissue of herring during frozen storage (chloroform layer of the extract). Description as for Fig. 1.

The oxidation process of the lipids of the muscle tissue containing no fruits nor BHA proceeded with high rate during frozen storage (Fig. 2). The addition of the sorb fruits, the mixture of the sorb and hawthorn fruits, and wild rose, as well as BHA, inhibited the buildup of the primary, as well as the secondary oxidation products at variable pace. The highest inhibition activity in the formation of hydroperoxides was exhibited by BHA, 
secondly - by the wild rose fruits, and then by the mixture of the sorb and hawthorn fruits, and the sorb fruits alone. The hawthorn fruits solely did not show such properties. Only within the mixture with the sorb, and in the twice lower concentration, they reached ability to slow down the oxidation of lipids of the muscle tissue of herring to peroxides (Fig. 2).

The buildup of the secondary oxidation products (TBARS) and the conjugated dienes and trienes occurred at the slowest pace under the influence of the wild rose fruits, secondly-BHA. The activity of the sorb fruits was similar to the antioxidative activity of BHA. At slightly lower degree it was shown by the fruits of hawthorn and the sorb tree (Figs. 3-5). The malonaldehyde content in the herring muscle tissue during frozen storage, exhibited linear relationship with the content of conjugated trienes in the fish lipids (Fig. 6). The correlation coefficients were significant for the level of $p=0.01$ for the samples containing the addition of the hawthorn fruits. For the remaining-for the level of $p=0.001$ (Tab. 2).
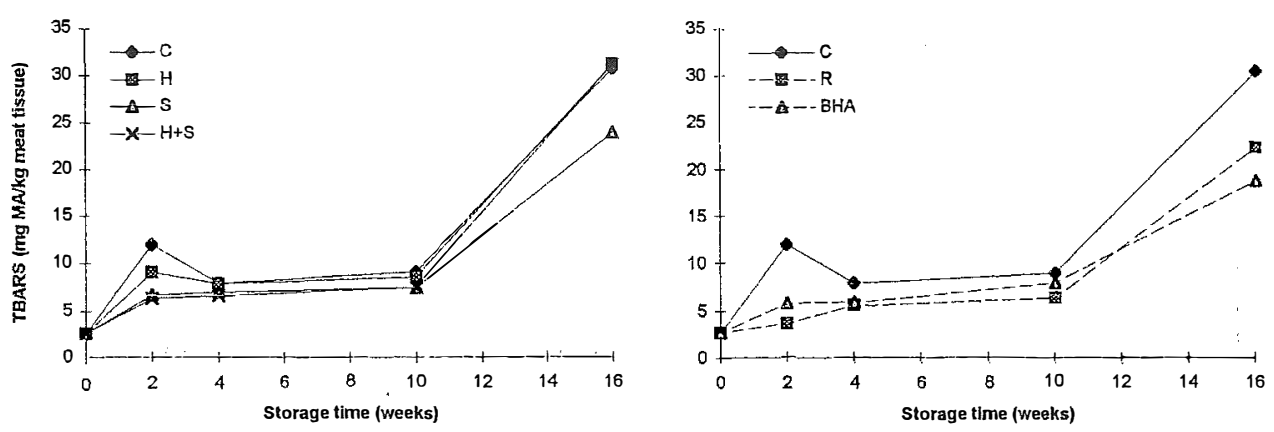

Fig. 3. Impact of the additives used for the content of malonaldehyde (TBARS) in the muscle tissue of herring during their freezing storage (methanol layer of extract). Description as for Fig. 1.

Considering the rate of the accumulation of all analyzed oxidation products (hydroperoxides, secondary oxidation products, conjugated dienes and trienes) in the muscle tissue of herring during the freezing storage - it has been revealed, that the most active inhibitor of lipids oxidation, among the additives used, were fruits of the wild rose, secondly BHA, and than their mixture with the fruits of hawthorn (Tab. 3). Antioxidative activity of BHA was lower at about $30 \%$ than the activity of the rose fruits. The hawthorn fruits alone did not slow down production of the studied products of lipids oxidation of the muscle tissue of herring. Symptomatic, however, was considerable moderation of the buildup of all the analyzed products of the lipids oxidation by the mixture of hawthorn and the sorb fruits (Tab. 3 ). It was probably caused by synergistic action of the constituents of both fruit species. The 
Table 2 synergists of the phenol compounds oc-

Correlation between malonaldehyde content and conjugated trienes of fatty acids in the muscle tissue of herring during frozen storage

\begin{tabular}{|l|c|c|}
\hline Kind of sample & $\begin{array}{c}\text { Correlation } \\
\text { coefficient }\end{array}$ & $\begin{array}{c}\text { Significance } \\
\text { of correlation } \\
\text { coefficient } \\
\text { (t value) }\end{array}$ \\
\hline Control & 0.973 & $15.434^{* *}$ \\
Additive used: & 0.721 & $3.290^{*}$ \\
Hawthorn & 0.981 & $15.907^{* *}$ \\
Sorb & 0.882 & $5.921^{* *}$ \\
Hawthorn + sorb & 0.920 & $7.421^{* *}$ \\
Rose & 0.983 & $16.891^{* *}$ \\
\hline BHA
\end{tabular}

*,** Correlation coefficient significant for $\mathrm{P}=0.01 ; \mathrm{P}=0.001$.

Table 3

Antioxidative activity (AA) of the additives used for the muscle tissue of herring during frozen storage

\begin{tabular}{|l|c|}
\hline \multicolumn{1}{|c|}{ Additive used } & AA (\%) \\
\hline Hawthorn & 0.0 \\
Hawthorn + sorb & 13.1 \\
Sorb & 15.2 \\
BHA & 20.2 \\
Rose & 28.9 \\
\hline
\end{tabular}

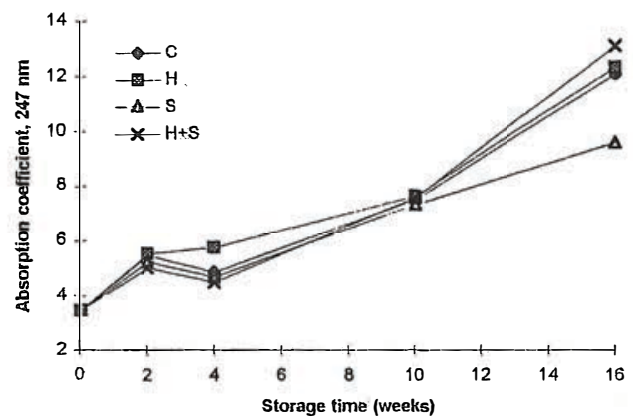
curring in plants are carboxylic acids (Danilova et al. 1992). The results of Lee et al. (1986) indicated the impact of $\mathrm{pH}$ of the muscle tissue on inhibition pace of plant-origin antioxidants (ginger rhizomes). According to these studies, the antioxidative activity grew along with $\mathrm{pH}$ drop from 7 towards acidic values. It suggests the importance of the organic acids occurring in plants, in their ability to inhibit the oxidation of fatty acids. According to the literature sources (Ożarowski and Jaroniewski 1989) fruits of the sorb tree contain substantial (reaching $0.2 \%$ ) amounts of vitamin $\mathrm{C}$, also such organic acids as: hydroxysuccinic, tartaric, sorbic, parasorbic, polyphenol acids, and also carotenoids including $\beta$-carotene. On the other hand the fruits of hawthorn contain small amounts of vitamin $\mathrm{C}$, flavonoids and other compounds.

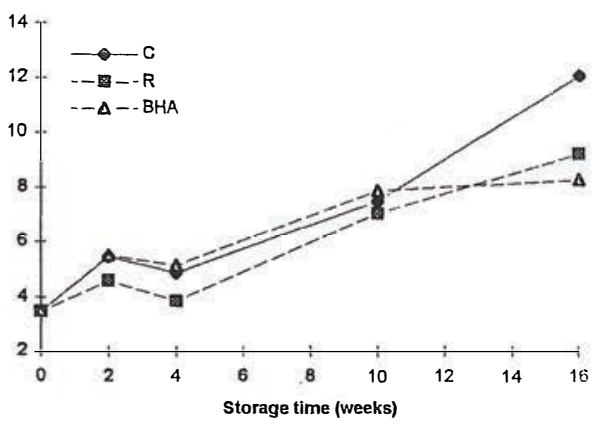

Fig. 4. Impact of the additives used, for the content of conjugated dienes of fatty acids in the lipids of muscle tissue of herring during frozen storage. Description as for. Fig. 1. 

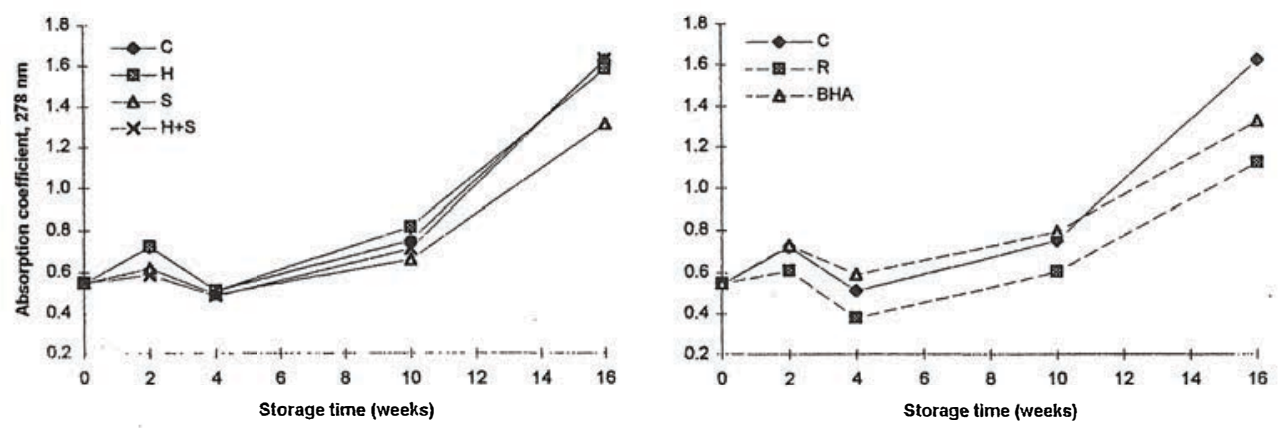

Fig. 5. Impact of the additives used, for the content of conjugated trienes of fatty acids in the lipids of muscle tissue of herring during frozen storage. Description as for. Fig. 1.

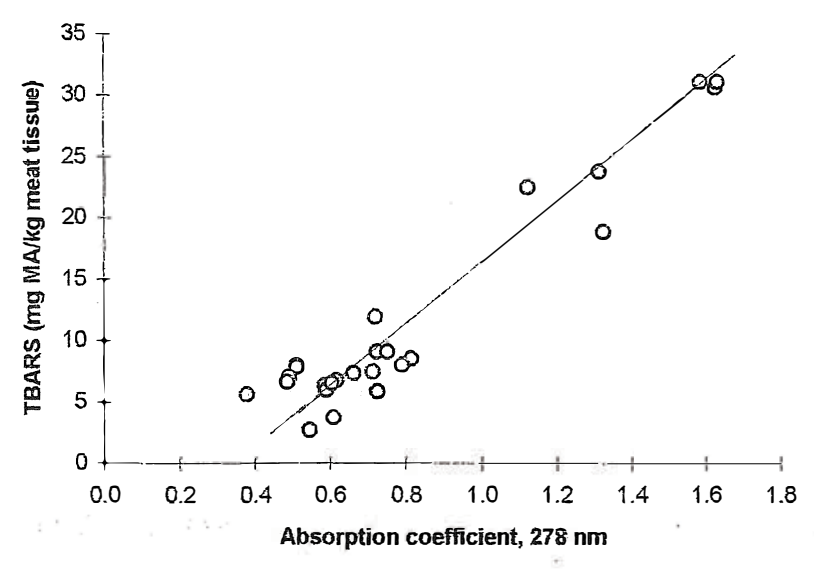

Fig. 6. Relationship between the content of trienes and the content of malonaldehyde during frozen storage of the herring muscle issue.
Comparing antioxidative activities of the wild rose fruits in the respects of lipids of the muscle tissue of herring, with such activity of wild rose seeds, applied at the same concentrations in the earlier studies (Stodoinik 1994), expressed in percent of the control sample values, it has been revealed that they are similar for both plant-origin additives. The activity of the wild rose fruits in the present studies was $28.9 \%$ while that of its seeds was $31.6 \%$ (Stodolnik 1994).

It was confirmed in the present studies, that the wild rose fruits were the only additive to lower the pace of the fatty acids release (Fig. 7). These fruits extended also the protective activities over the proteins of the muscle tissue of herring (Fig. 8). The similar properties towards proteins were exhibited by the sorb fruits, less distinct in the mixture with the hawthorn fruits, and the hawthorn fruits alone. Butylated hydroxyanisole did not change the amounts of soluble proteins in $5 \%$ solution of $\mathrm{NaCl}$, compared to the muscle tissue without any addtives during the freezing storage (Fig. 8). It is evident from the earlier studies 
(Stodolnik 1994) that the seeds of the wild rose (Rosa rugosa) are also protective factors for the muscle tissue of the herring stored at the temperature of $-25^{\circ} \mathrm{C}$.
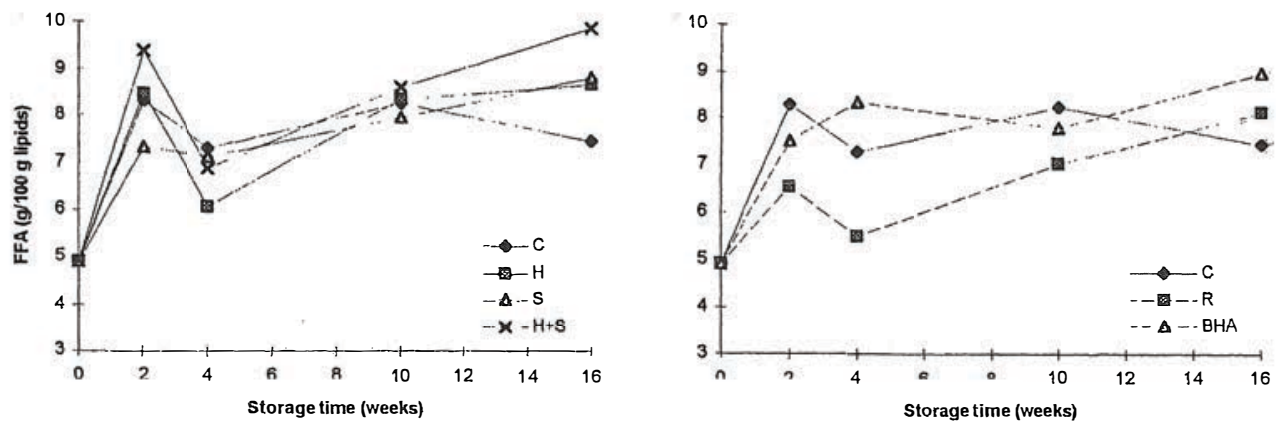

Fig. 7. Impact of the additives used, for the content of free fatty acids in the lipids of muscle tissue of herring during the freezing storage. Description as for Fig. 1.
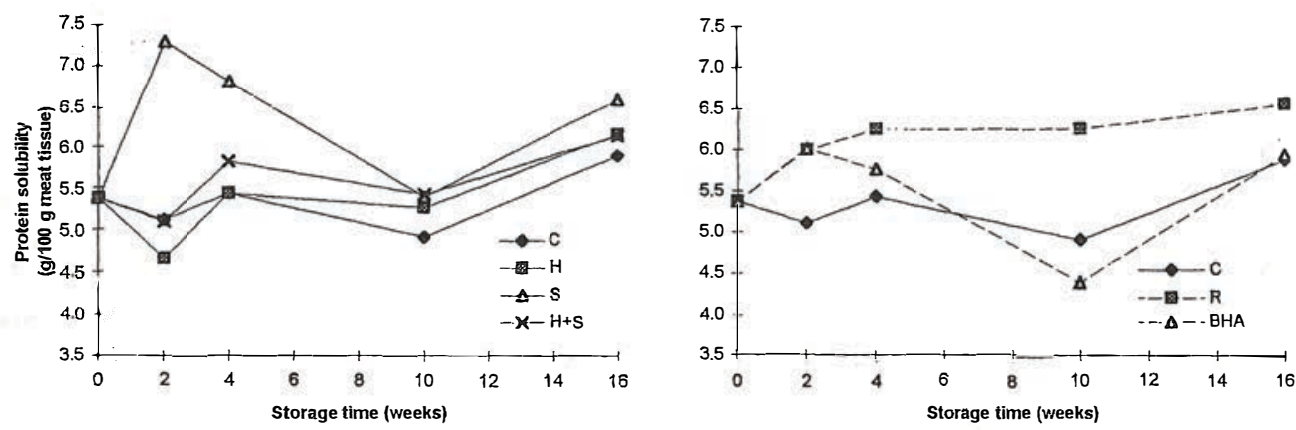

Fig. 8. Solubility of the proteins of the muscle tissue of herring in $5 \%$ solution of $\mathrm{NaCl}$ during the freezing storage. Description as for the Fig. 1.

\section{RECAPITULATION}

It is evident from the present studies, that the addition of the wild rose fruits, at the concentrations of $0.5 \%$, to the minced muscle tissue of herring stored at the freezing temperatures, can be used for inhibition of lipids oxidation. Furthermore the above additive was at about $30 \%$ more active than the BHA used at the concentrations of $0.01 \%$ for the same row material.

Fruits of the sorb tree should be considered also as a source of natural antioxidatives, not as abundant, however, as the wild rose fruits. Fruits of the hawthorn, contain probably 
synergetic compounds acting on antioxidatives occurring in the sorb tree fruits. The former fruits used alone, did not show effect on the lipids of herring muscle tissue, while used in the mixture with the sorb tree fruits multiplied the antioxidative activity of the latter.

\section{REFERENCES}

Al-Saikhan M.S., L.R. Howard, J.C. Miller jr., 1995: Antioxidant activity and total phenolics in different genotypes in potato (Solanum tuberosum L.). J Food Sci., 60, 2: 341-343, 347.

Bartnikowska E., 1995: Health benefits of dietary antioxidants. Pol. Food Nutr. Sci., 45, 4: 3-22.

Czermiński J., A. Iwasiewicz, Z. Paszek, A. Sikorski, 1974: Metody statystyczne w doświadczalnictwie chemicznym [Statistical methods in chemical experiments]. PWN, Warszawa, 170-189. (In Polish).

Danilova L.A., Černova, F.E. Ickov, I.N. Demidov, 1992: Antooksaidantnyje svojstva i soderžanije fenolnych soedinenij $\mathrm{v}$ rastitelnych ekstraktach [Antioxidative properties and phenolic compounds content in plant extracts]. Pišč. Promysl., No 10: 7-8. (In Russian).

Larson R.A., 1988: The antioxidants of higher plants. Phytochemistry, 27: 969-978.

Linko R.R., 1967: Fatty acids and other components of Baltic herring flesh lipids. Ann. Univ. Turku, Ser. A, 101: 7-121.

Löliger J., 1989: Natural antioxidants. In: Rancidity in Foods [Allen J.C., R.J. Hamilton (eds.)], Elsevier Applied Science, London-New York, 105-124.

Love R.M., 1988: The food fishes their intrinsic variation and practical implications. Farrand Press, London, 3-23.

Ożarowski J., W. Jaroniewski, 1989: Rośliny lecznicze i ich praktyczne zastosowanie [Medical plants and their practical application]. IWZZ, Warszawa, 288-289. (In Polish).

Pratt D.E., B.M. Watts, 1964: The antioxidant activity of vegetable extracts. 1. Flavone aglycones. J. Food Sci., 29: 27-33.

St Angelo A.J., K.L. Crippen, H.P. Dupuy, C. James jr., 1990: Chemical and sensory studies of antioxidant, treated beef. J. Food Sci., 55: 1501-1505, 1539.

Stodolnik L., 1994: Zastosowanie naturalnych antyoksydantów do rozdrobnionej tkanki mięśniowej śledzi bałtyckich przechowywanej w warunkach zamrażalniczych [Using of natural antioxidants to herring minced meat tissue stored in frozen conditions]. Chłodnictwo, No. 10: 21-25. (In Polish).

Stodolnik L., 1995: Activity of selected plant raw materials in inhibition lipids changes Baltic herring minced meat tissue during frozen storage. Acta Ichth. Piscat., 25, 1: 79-87. 
Ludmiła STODOLNIK

\section{HAMOWANIE UTLENIANIA LIPIDÓW ZMIELONEJ TKANKI MIEŚSIOWEJ ŚLEDZI PRZEZ ZASTOSOWANIE WYBRANYCH OWOCÓW W WARUNKACH ZAMRAŻALNICZEGO PRZECHOWYWANIA}

\section{STRESZCZENIE}

W badaniach zastosowano suszone owoce dzikiej róży $(0,5 \%)$, jarzębiny $(0,5 \%)$, glogu $(0,5 \%)$ oraz mieszaninę owoców jarzębiny $(0,25 \%)$ i głogu $(0,25 \%)$ do zmielonej tkanki mięśniowej śledzi baltyckich przechowywanej w temperaturze $-25^{\circ} \mathrm{C}$. Właściwości przeciwutleniające zastosowanych owoców określano w stosunku do surowca bez takich dodatków oraz zawierającej BHA $(0,01 \%)$. Szybkość utleniania lipidów tkanki mięśniowej śledzi określano na podstawie zawartości hydronadtlenków, aldehydu malonowego, skoniugowanych dienów i trienów. Uzyskane wyniki wykazały, że najszybsze spowalnianie utleniania lipidów zachodzilo w tkance mięśniowej śledzi zawierającej dodatek owoców róży, a ich przeciwutleniająca aktywność wynosiła $28,9 \%$ i była wyższa o około $30 \%$ od aktywności BHA. Owoce jarzębiny inhibitowaly utlenianie lipidów w $15,2 \%$, mieszanina owoców jarzębiny i głogu w 13,1\% w stosunku do tkanki mięšniowej nie zawierającej dodatków. Same owoce głogu były obojętne w stosunku do lipidów tkanki mięśniowej śledzi przechowywanej w warunkach zamrażalniczych.

Received: 21 May 1996

Authors' address:

Ludmila Stodolnik PhD DSc Prof Tit

Department of Fish Preservation

Agricultural University of Szczecin,

Kazimierza Królewicza 4, 71-550 Szczecin, Poland 